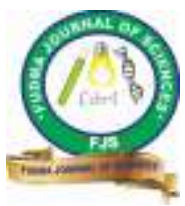

FUDMA Journal of Sciences (FJS)

ISSN online: $2616-1370$

ISSN print: 2645 - 2944

Vol. 4 No. 2, June, 2020, pp 53 - 59

DOI: https://doi.org/10.33003/fjs-2020-0402-109

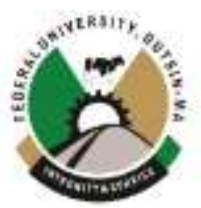

\title{
GROWTH PERFORMANCE, NUTRIENT UTILIZATION, SURVIVAL AND BODY INDICES OF AFRICAN CATFISH (CLARIAS GARIEPINUS, BURCHELL 1822) REARED ON MAGGOT MEAL BASED DIET
}

\author{
${ }^{* 1}$ Akinwole, A. O., ${ }^{2}$ Dauda, A. B. and ${ }^{1}$ Ogunkunle, V. O. \\ ${ }^{1}$ Department of Aquaculture and Fisheries Management, University of Ibadan, Ibadan, Nigeria \\ ${ }^{2}$ Department of Fisheries and Aquaculture, Federal University Dutsin-Ma, Dutsin-Ma, Katsina State, Nigeria \\ *Corresponding author's email: tdabak@gmail.com +2348062085120
}

\begin{abstract}
Growth performance, nutrient utilization, survival and body indices of African catfish Clarias gariepinus juveniles fed diets containing maggot meal as total replacement of fish meal was evaluated for 42 days. A total number of 60 fingerlings of Clarias gariepinus with average weight of $10 \mathrm{~g}$ were randomly distributed into six circular tanks (Diameter of $45 \mathrm{~cm}$ and depth of $29 \mathrm{~cm}$ ) at the rate of 10 fish per tank. There were two treatments, DT1 (maggot meal based diet) and DT2 (fish meal based diet) of 28.70 and $34.65 \%$ CP respectively and triplicated. The fish were fed twice a day. Water quality parameters were monitored on a weekly basis throughout the experimental period. Growth, nutrient utilization and body indices parameters were evaluated at the end of experiment. Crude protein, crude lipid and ash were higher in fish meal based, while crude fibre was higher in maggot meal based diet. The selected water quality parameters were not different significantly $(\mathrm{P}>0.05)$ between the treatments. Mean weight gain, specific growth rate, protein intake, protein efficiency ratio, lipid intake and lipid efficiency ratio $(17.25 \pm 0.70 \mathrm{~g}, 2.39 \pm 0.06 \% /$ day, $95.50 \pm 1.27 \mathrm{~g}, 1.81 \pm 0.06$, $23.96 \pm 0.32 \mathrm{~g}$ and $7.20 \pm 0.24$ respectively) were all significantly higher $(\mathrm{P}<0.05)$ in $\mathrm{DT} 2$. Feed conversion ratio was higher significantly $(\mathrm{P}<0.05)$ in DT1. Survival, hepatosomatic index and condition factor were similar $(\mathrm{P}>0.05)$ between the two treatments. Though, the aforementioned body indices indicated that the total replacement of fish meal with maggot meal is not harmful to the fish, a partial replacement may be better for optimum output.
\end{abstract}

Keywords: Clarias gariepinus; fish meal; maggot meal; Nutrient utilization

\section{INTRODUCTION}

The world food fish production is tending towards reliance on aquaculture, as capture fisheries is facing increased challenges of over exploitation of stocks, aquatic pollution and climate change with the attendant consequences of reduced quantity of fish catch (Dauda et al., 2018a). Aquaculture's contribution to the global fish supply is steadily increasing in recent times, where it has gone from 73.7 million tonnes in 2014 to 80 million tonnes in 2016, representing an increase from $44.69 \%$ to $46.81 \%$ of global fish production in just two years (FAO, 2018). In Nigeria, aquaculture production is also growing steadily albeit some constraints. Among these constraints, cost of fish feed is classified as a major constraint (Dauda et al., 2015). The high cost of fish feed is largely dictated by the cost of animal protein source which is mainly fish meal (Dasuki et al., 2014; Daniel, 2018). There have been continuous efforts to either reduce fish meal inclusion or totally replace it with some other feed ingredients. For instance, El-Sayed et al., (1998) experimented on replacement of fish meal with shrimp meal, blood meal, meat and bone meal, poultry by-product meal, and a combination of blood meal, meat and bone meal in the diet of Oreochromis niloticus. More readily available protein sources are plant proteins, but many of them can only serve for partial and not total replacement. Plant ingredients contain various levels of anti-nutritional factors, with less nutrients digestibility, as well as problems of nutrients bio-availability and palatability (De Francesco et al., 2004; Engin et al., 2005; Bonaldo et al., 2011). Most researchers opined that fish meal can only be partially replaced with plant protein sources (Daniel, 2018). However, the lesser the amount of fish meal in fish feed the cheaper the potential cost of the feed. Therefore, the needs to continuously seek potentially cheaper animal sources that can effectively replace fish meal. Maggot meal is a quality protein source produced from waste material of either plant or animal origin, with crude protein content of between 43 and 48\%. (Fasakin et al., 2003; Aniebo et al., 2009; Michael and Sogbesan, 2015). Fasakin et al. (2003) replaced fish meal with differently processed maggot meals, sun-dried full-fat, defatted oven-dried and defatted sun-dried. The authors reported a significantly reduced daily weight gain, protein efficiency ratio and specific growth rate in sun-dried maggot meal. There was no significant difference between the defatted maggot meal treatments and fish meal treatment. However, further treatment of maggot meal by defattening may increase the cost of production of the maggot 
meal and eliminate the price advantage of the maggot meal ahead of fish meal. Michael and Sogbesan (2015) experimented with various percentage replacement of fish meal with maggot meal and single cell protein. The best growth performance was obtained in the treatment with $30 \%$ fish meal and $10 \%$ maggot meal followed by the control with neither maggot meal nor single cell protein. The worst result was obtained in the treatment that had single cell protein completely replacing fish meal. The needs for further experimentation on the replacement of fish meal with maggot meal is a continuous efforts, in order to possibly standardise the use of maggot meal in the diet of fish. This study experimented on the complete replacement of fish meal with maggot meal in the diet of African catfish (Clarias gariepinus) juveniles.

\section{MATERIALS AND METHODS}

\section{Experimental site, facilities and animal source}

The experiment was conducted in the Research Laboratory of Department of Aquaculture and Fisheries Management, University of Ibadan, Ibadan, Nigeria. Six plastic tanks each with a diameter of $45 \mathrm{~cm}$ and depth of $29 \mathrm{~cm}$ were used for the experiment. Each of the tanks was filled with 25 litres of water, and designated for the two treatments in triplicates. The systems were stagnant-water renewal systems with $50 \%$ water change twice a week. The treatment 1 (DT1) was for maggot meal treatment while treatment 2 (DT2), the control, was for the fish meal treatment. Sixty African catfish (Clarias gariepinus) juveniles, with average weight of $10 \mathrm{~g}$ were purchased from a local fish farm in Ibadan, Oyo State. The fish were transferred in 25 litres plastic container partially opened at the top for exchange of gas. The fish were acclimatized for five days in the previously prepared plastic tanks in the laboratory. The fish were fed commercial pellet of $40 \% \mathrm{CP}$ and $2 \mathrm{~mm}$ size during acclimation.

\section{Maggot meal processing and diet formulation}

Maggots were collected from the layers chicken production units at University of Ibadan Teaching and Research Farm Ibadan, Nigeria. The maggots collected were washed properly so as to remove dirty materials (like faecal dropping of the poultry birds, feather etc.) and then put inside plastic containers. The maggots were covered inside containers for over two hours until they all died, after which they were dried by spreading on aluminium trays under the sun for 7 days. The dried maggots were then pulverized with an electric blender. The powdered maggot meal was kept in a clean, air tight plastic container. The diet was formulated by using the following ingredients, soybean, fish oil, bone meal, vitamin premix, groundnut cake, corn bran, wheat bran and starch (Table 1) except for substitution of fishmeal for maggot meal weight for weight. The maggot meal based diet contained 30\% maggot meal while the fish meal based diet contained $30 \%$ fish meal. The various ingredients were grinded into fine powdery form and thoroughly mixed in a bowl to form a homogenous mixture. Premix, warm water and starch were added to the ingredients and were thoroughly mixed together. The feed was then pelletized using grinding machine enhanced with $2 \mathrm{~mm}$ die. The pellets were sundried, labelled and packaged in an air tight bag. Samples of the two diets were taken to the laboratory for proximate analysis following standard methods (AOAC, 2012)

Table 1: Gross composition of the experimental diets per $100 \mathrm{~g}$

\begin{tabular}{lll}
\hline Ingredients $(\mathrm{g})$ & DT1 (maggot meal based diet) & DT2 (fish meal based diet) \\
\hline Fish meal $(72 \%)$ & - & 30 \\
Maggot meal & 30 & - \\
Soybean & 20.3 & 20.3 \\
GNC & 20.3 & 20.3 \\
Corn bran & 12.4 & 12.4 \\
Wheat bran & 12.4 & 12.4 \\
Bone meal & 1.0 & 1.0 \\
Fish oil & 1.0 & 1.0 \\
Premix & 1.0 & 1.0 \\
Common salt & 1.0 & 1.0 \\
Starch & 0.6 & 0.6 \\
\hline Total & 100 & 100 \\
\hline
\end{tabular}

\section{Experimental procedure}

There were two treatments $\mathrm{DT}_{1}$ (maggot meal based treatment) and $\mathrm{DT}_{2}$ (fishmeal based treatment), and the design used was completely randomized design (CRD). Each tank was stocked with 10 fish (average weight of $10 \mathrm{~g}$ ) each making a total of 60 fish used for the experiment. The juvenile were fed twice daily (morning and evening) at $5 \%$ body weight, the amount of feed supply are adjusted weekly based on the change in weight observed during weekly sampling. Water quality parameters were measured weekly. The selected physico-chemical parameters were $\mathrm{pH}$, ammonia, nitrite, nitrate, temperature and dissolved oxygen. The water quality parameters were measured following procedures described by Dauda et al. (2014). 
Growth performance, nutrient utilization, survival and body indices evaluation

The length and weight of fish in each tank were measured weekly, and the amount of feed per week was also evaluated. Data obtained were used to calculate various performance evaluation parameters using the equations below as described by Akinwole et al. (2014) and Dauda et al. (2018b):

Weight gain

$$
\text { WG }(g)=\text { final weight }(g)-\text { initial weight }(g)
$$

Mean Weight gain

$$
\text { MWG }(\mathrm{g})=\text { Weight gain }(\mathrm{g}) / \mathrm{Number} \text { of fish }
$$

Specific growth rate

$$
\begin{gathered}
\text { SGR }(\% / \text { day })=\quad\left(\mathrm{Ln} \mathrm{W}_{2}-\mathrm{Ln} \mathrm{W}_{1}\right) \times 100 / \text { Number of Culture days } \\
\text { Where } \mathrm{W}_{1}=\text { initial weight } \\
\mathrm{W}_{2}=\text { final weight } \\
\mathrm{Ln}=\text { Natural logarithms }
\end{gathered}
$$

Feed conversion ratio

$$
\mathrm{FCR}=\quad \text { Dry weight of feed consumed }(\mathrm{g}) / \text { Wet weight gain }(\mathrm{g})
$$

Protein intake

$$
\mathrm{PI}(\mathrm{g})=\% \text { protein content of the feed } \mathrm{x} \text { total feed intake }(\mathrm{g})
$$

Protein efficiency ratio

$$
\mathrm{PER}=\text { wet weight gain }(\mathrm{g}) / \text { protein intake }(\mathrm{g})
$$

Lipid intake

Lipid intake $(\mathrm{g})=\%$ lipid in feed $\mathrm{x}$ amount of feed consumed $(\mathrm{g})$

Lipid efficiency ratio

Lipid efficiency ratio = wet weight gain of fish/lipid intake of the fish

Condition factor $(\mathrm{k})$

$\mathrm{K}=\mathrm{w} \times 100 / \mathrm{L}^{3}$

Where $\mathrm{w}=$ weight of fish

$\mathrm{L}=$ standard length of fish

Survival

$\%$ Survival $=$ Total number of fish harvested $\mathrm{x}$ 100/Total number of fish stocked

Hepatosomatic index

$$
\text { HSI }(\%)=\quad \text { Liver weight }(\mathrm{g}) \times 100 / \text { Body weight }(\mathrm{g})
$$

\section{Statistical Analysis}

The mean value ( \pm standard deviation) for each growth parameters, nutrient utilization, body indices and water quality parameters were determined using descriptive statistics. Independent sample t-test was used to establish the significant differences between the two treatments for each of the parameters measured at $95 \%$ confidence interval.

\section{RESULTS}

The results of the proximate analysis of the experimental diets are shown in Table 2, crude protein, lipid and ash were higher in fish meal based treatment, $34.65 \%, 7.33 \%$ and $18.03 \%$ respectively, while $28.70 \%, 7.20 \%$ and $11.01 \%$ were recorded in maggot meal based diet. The crude fibre was slightly higher in maggot meal based diet. 
Table 2: Proximate analysis $(\%)$ of the experimental diets

\begin{tabular}{llc}
\hline Parameters & $\begin{array}{l}\text { DT1 (Maggot meal based } \\
\text { treatment) }\end{array}$ & DT2 (Fish meal based treatment \\
\hline Crude protein & 28.70 & 34.65 \\
Crude fibre & 3.90 & 3.30 \\
Crude ash & 11.01 & 18.03 \\
Crude lipid & & 7.33 \\
Dry matter & 7.20 & 91.05
\end{tabular}

The results of the selected water quality parameters are presented in Table 3 . The water quality parameters were generally similar between the two treatments with only slight differences in some of the parameters, but the differences were not significant $(\mathrm{P}>0.05)$ for any of the parameters. Nitrate-nitrogen and nitrite-nitrite-nitrogen were below level of detection. The dissolved oxygen and ammonia-nitrogen were slightly higher in DT2.

Table 3: Mean $( \pm$ SD) selected water quality parameters of fish culture with different diets

\begin{tabular}{llc}
\hline Parameters & $\begin{array}{c}\text { DT1 (Maggot meal based } \\
\text { treatment) }\end{array}$ & $\begin{array}{c}\text { DT2 (Fish meal based } \\
\text { treatment }\end{array}$ \\
\hline Dissolved oxygen(mg/L) & $2.76 \pm 0.10$ & $2.92 \pm 0.09$ \\
pH & $6.70 \pm 0.02$ & $6.72 \pm 0.02$ \\
Nitrate-nitrogen $(\mathrm{mg} / \mathrm{L})$ & $0.00 \pm 0.00$ & $0.00 \pm 0.00$ \\
Nitrite-nitrogen $(\mathrm{mg} / \mathrm{L})$ & & $0.00 \pm 0.00$ \\
Ammonia-nitrogen $(\mathrm{mg} / \mathrm{L})$ & $0.00 \pm 0.00$ & $2.1 \pm 0.11$ \\
Temperature $\left({ }^{\circ} \mathrm{C}\right)$ & $2.00 \pm 0.00$ & $25.28 \pm 0.14$
\end{tabular}

The results of the growth and nutrients utilization performance of the fish cultured with the two diets are presented in Table 4. All the growth performance indices; final biomass, weight gain, mean weight gain, mean daily weight gain and specific growth rate were significantly higher $(\mathrm{P}<0.05)$ in fish meal based treatment compared to maggot meal based treatment. While the feed conversion ratio was significantly lower $(\mathrm{P}<0.05)$ in the fish meal based treatment, other nutrient utilization parameters, including total feed intake, protein intake, protein efficiency ratio, lipid intake and lipid efficiency ratio were higher significantly in fish meal based treatment. No mortality was experienced in any of the treatments throughout the experimental period. The condition factor and hepatosomatic index were significantly not different $(\mathrm{P}>0.05)$ between the two treatments. 
Table 4: Growth performance, nutrient utilization and body indices of Clarias gariepinus fed with Maggot meal based and fish meal based diets

\begin{tabular}{lcl}
\hline Parameters & $\begin{array}{c}\text { DT1 (Maggot meal based } \\
\text { treatment) }\end{array}$ & DT2 (Fish meal based treatment) \\
\hline Duration of study (days) & 42 & 42 \\
Initial biomass (g) & $100.00 \pm 0.03$ & $100.00 \pm 0.04$ \\
Final biomass $(\mathrm{g})$ & $227.00 \pm 3.53^{\mathrm{b}}$ & $272.50 \pm 7.00^{\mathrm{a}}$ \\
Weight gain $(\mathrm{g})$ & $127.00 \pm 3.54^{\mathrm{b}}$ & $172.50 \pm 7.00^{\mathrm{a}}$ \\
Mean weight gain (g) & $12.70 \pm 0.35^{\mathrm{b}}$ & $17.25 \pm 0.70^{\mathrm{a}}$ \\
Mean daily weight gain (g/day) & $0.30 \pm 0.01^{\mathrm{b}}$ & $0.41 \pm 0.02^{\mathrm{a}}$ \\
Specific growth rate (\%/day) & $1.95 \pm 0.04^{\mathrm{b}}$ & $2.39 \pm 0.06^{\mathrm{a}}$ \\
Total feed fed intake (g) & $299.55 \pm 9.97^{\mathrm{b}}$ & $332.77 \pm 4.41^{\mathrm{a}}$ \\
Feed conversion ratio & $2.36 \pm 0.01^{\mathrm{a}}$ & $1.93 \pm 0.06^{\mathrm{b}}$ \\
Protein intake (g) & $85.97 \pm 2.86^{\mathrm{b}}$ & $95.50 \pm 1.27^{\mathrm{a}}$ \\
Protein efficiency ratio & $1.48 \pm 0.01^{\mathrm{b}}$ & $1.81 \pm 0.06^{\mathrm{a}}$ \\
Lipid intake (g) & $21.57 \pm 0.72^{\mathrm{b}}$ & $23.96 \pm 0.32^{\mathrm{a}}$ \\
Lipid efficiency ratio & $5.89 \pm 0.03^{\mathrm{b}}$ & $7.20 \pm 0.24^{\mathrm{a}}$ \\
Survival rate $(\%)$ & $100.00 \pm 0.00$ & $100.00 \pm 0.00$ \\
& & \\
Condition factor & $1.15 \pm 0.01$ & $1.17 \pm 0.03$ \\
Hepatosomatic index $(\%)$ & & \\
& $1.70 \pm 0.47$ & $0.97 \pm 0.43$ \\
\hline
\end{tabular}

${ }^{+}$Values are Mean of three readings $( \pm \mathrm{SD})$, different superscripts in each row indicate significant difference $(\mathrm{P}<0.05)$

\section{DISCUSSION}

The success of aquaculture practices largely depend on ability to make quality feed with appropriate nutrient values available to cultured fish. C. gariepinus is an omnivorous fish with relatively high protein requirements. Several researchers have reported the nutrients requirements of African catfish fingerlings/juveniles with variations. While pioneer research reports suggested $40 \%$ crude protein as optimum crude protein requirements (Faturoti et al., 1986; Degani et al., 1989). Recent research reports have reported as low as 30 and $25 \%$ crude protein in the diet of African catfish without negative consequences (Abu Bakar et al., 2015; Mwangi et al., 2018). The crude protein of 28.70 and $34.65 \%$ in DT1 and DT2 respectively in this research are within the previously reported range and should be able to support the efficient growth of the fish cultured. Higher lipid and ash content in DT2 which already has higher crude protein content may be giving the diet advantages ahead of DT1. The water quality parameters are not influenced by the different diets, as this is evident in the similarities of the selected water quality parameters. All the water quality parameters are within the range for safe culture of tropical fish species like $C$. gariepinus and discharge into the environment without negative consequences (Dauda et al., 2014; Dauda et al., 2018b). The growth and nutrient utilization parameters were better in the fish meal based diet. This may not only be due to the higher crude protein and lipid but also the quality of the crude protein and fatty acid composition. However, the protein quality, amino acid and fatty acid composition were not examined in this study. Fish meal has been found difficult to be completely replaced in the diet of fish because of the quality of its essential amino acids combination (Dasuki et al., 2014). The results obtained in the research are similar to that of total replacement of fish meal with sun-dried maggot meal by Fasakin et al. (2003). Michael and Sogbesan (2015) also reported better results in fish meal based diet and a combination of fish meal and maggot meal compared to other treatments that involved total replacement of fish meal with either maggot meal, single cell protein or a combination of the two. The hepatosomatic index was not different significantly between the treatments and it is within the same range previously observed for C. gariepinus (Dauda et al., 2017; Dauda et al., 2018b). The similarity in hepatosomatic index is an indication that the fish were not stressed and that the livers are in good condition. So it is sufficient to say that both the water quality and feeds experimented are adequate for fish culture. Survival rate and condition factor were also similar between the two treatments, further indicating that total replacement of fish meal with maggot meal tends not to affect the well-being of the fish.

\section{CONCLUSION}

It can be established from this research that maggot meal that can be readily available without any threat of over exploitation of natural resources like the case of fish meal and perhaps at cheaper cost can be used as a source of protein in fish feed. However, it may be better for partial replacement and not total 
replacement of fish meal. A further research to establish the optimum replacement level is therefore recommended.

\section{REFERENCES}

Abu Bakar, N. S., Mohd Nasir, N., Lananan, F., Abdul Hamid, S. H., Lam, S. S. and Jusoh, A. (2015). Optimization of C/N ratios for nutrient removal in aquaculture system culturing African catfish, (Clarias gariepinus) utilizing Bioflocs Technology. International Biodeterioration and Biodegradation, 102: 100-106.

Akinwole, A.O., Dauda, A.B. and Nwolisa, E.C. (2014). Influence of culture water draw off on growth of the African catfish (Clarias gariepinus, Burchell 1822) cultured under integrated system. International Journal of Applied Agricultural and Apicultural Research 10, 139-147.

Aniebo, A.O., Erondu, E.S. and Owun, O.J. (2009). Replacement of fish meal with maggot meal in African catfish (Clarias gariepinus) diets. Revista Cientifica UDO Agricola 9, $666-671$.

AOAC (2012). Official Methods of Analysis of AOAC International, 19th edition. Association of Official Analytical Chemists, Gaithersburg, MD.

Bonaldo, A., Parma L., Mandrioli L., Sirri, R.,. Fontanillas, R., Badiani, A. and Gatta, P.P. (2011). Increasing dietary plant proteins affects growth performance and ammonia excretion but not digestibility and gut histology in turbot (Psetta maxima) juveniles. Aquaculture 318(1),101-108.

Daniel, D. (2018). A review on replacing fish meal in aqua feeds using plant protein sources. International Journal of Fisheries and Aquatic Studies 6(2), 164-179.

Dasuki, A., Dauda, A.B. and Oshoke, J.O. (2014). Preliminary investigation of Nutritional Quality of Senna obtusifolia for Potential Use in Fish feed. American-Eurasian Journal of Sustainable Agriculture 8(5):94-98.

Dauda, A.B., Akinwole, A.O., and Olatinwo, L.K. (2014).Biodenitrification of aquaculture waste water at different drying times in water reuse system. Journal of Agriculture and Food Technology, 4(2) 6-12.

Dauda, A.B., Dasuki, A. and Bichi, A.H. (2015). Analysis of Constraints to Aquaculture Development in Sudano-Sahelian Region of Nigeria. Tropical and Subtropical Agroecosystems 18, 189-193.

Dauda, A.B., Romano, N., Ebrahimi, M., Karim, M., Ikhsan, N., Kamarudin, M.S., Ekasari, J. (2017). Different Carbon Sources Affects Biofloc Volume, Water Quality and The Survival and Physiology of African Catfish Clarias gariepinus Fingerlings Reared in Intensive Biofloc Technology System. Fisheries
Science, 83, 1037-1048.

Dauda, A.B., Natrah, I., Karim, M., Kamarudin, M.S. and Bichi, A.H. (2018a). African Catfish Aquaculture in Malaysia and Nigeria: Status, Trends and Prospects. Fisheries and Aquaculture Journal 9: 237. doi:10.4172/2150-3508.1000237.

Dauda, A.B., Romano, N., Wee, W.C., Ikhsan, N., Kamarudin, M.S. (2018b). Differences in feeding habits influence the growth performance and feeding efficiencies of African catfish (Clarias gariepinus) and lemon fin barb hybrid (Hypsibarbus wetmorei $\widehat{\sigma} \times$ Barboides gonionotus + ) in a glycerol-based biofloc technology system versus a recirculating system. Aquacultural Engineering 82, 31-37.

De Francesco, M., Parisi, G., Médale, F., Lupi, P., Kaushik, S.J. and Poli, B.M. (2004). Effect of long-term feeding with a plant protein mixture based diet on growth and body/fillet quality traits of large rainbow trout (Oncorhynchus mykiss). Aquaculture 236(1), 413-429.

Degani. G., Ben-Zvi. Y. and Levanon. D. (1989). The effect of different protein levels and temperatures on feed utilization, growth and body composition of Clarias gariepinus (Burchell 1822). Aquaculture 76, 293-301.

El-Sayed, A.F.M. (1998). Total replacement of fish meal with animal protein sources in Nile tilapia, Oreochromis niloticus (L.)., feeds. Aquaculture Research 29(4), 275-280.

Engin, K. and Carter, C.G. (2005) Fish meal replacement by plant and animal by-products in diets for the Australian shortfinned eel, Anguilla australis australis (Richardson). Aquaculture Research 36(5), 445- 454.

FAO. (2018). The State of World Fisheries and AquacultureMeeting the Sustainiable Development Goals. Fisheries and Aquaculture Department, Food and Agriculture Organization of the United Nations, Rome.

Fasakin, E. A., Balogun, A.M. and Ajayi, O.O. (2003). Nutrition implication of processed maggot meals; hydrolyzed, defatted, full-fat, sun-dried and oven-dried, in the diets of Clarias gariepinus fingerlings. Aquaculture Research 9 (34), 733-738.

Faturoti, E.O., Balogun, A.M. and Ugwu, L.C. (1986). Nutrient utilization and growth responses of Clarias fed different protein levels. Nigerian Journal of Appied Fisheries and Hydrobiology 1, 31-49.

Michael, K.G., and Sogbesan, O.A. (2015). Evaluation of Maggot Meal (Musca domestica) and Single Cell Protein (Mushroom) in the Diet of Clarias gariepinus Fingerlings 
(Burchell, 1822). Fisheries and Aquaculture Journal 6: 133. doi:10.4172/2150-3508.1000133.

Mwangi, J. M., Maina, J. G. and Gachuiri, C. K. (2018). Effects of dietary protein levels on performance of African catfish Clarias gariepinus in fertilized and unfertilized earthen ponds. Livestock Research for Rural Development. Volume 30, Article \#48. Retrieved July 13, 2019, from http://www.lrrd.org/lrrd30/3/jacks30048.html. use, distribution, and reproduction in any medium, provided the original work is cited appropriately. 